\title{
Court Management of AIDS Disputes: A Sociolegal Analysis
}

\section{Michael C. Musheno, Peter R. Gregware, and Kriss A. Drass}

Historically, disease scares reveal contradictions in the social order. We postulate that courts focus on depoliticizing social tensions revealed by AIDS, legitimating the routines of dominant parties in the AIDS sociolegal network. At the same time, courts deviate from their normal practices by upholding the claims of subordinate parties in this network, particularly people living with AIDS (PWAs) and their allies. Our analysis of 36 AIDS-related court rulings, published during the formative years of AIDS litigation in the United States, supports the notion that courts operate as "double-edged" institutions. To explain the duality of judicial decision making, we concentrate on the powers of social and cultural factors rather than on the doctrinal judgments of the courts. We trace how relational attributes, evident in contestants' characteristics (e.g., plaintiff/defendant, status differentials) and the nature of claims (i.e., restrictive/expansive), combine to account for wins for dominant parties and how other combinations of these attributes define wins for subordinate parties. We also show how judges combine specific interpretational attributes in the text of their rulings (e.g., use of divisive AIDS metaphors, deference to medical authority) to justify wins. We consolidate these findings to discuss how PWAs and their allies might use the courts to their

Michael C. Musheno is a professor of justice studies and public affairs at Arizona State University, School of Justice Studies. Ph.D. 1974, American University. Currently, he is on leave to the National Science Foundation, serving as visiting scientist and program director, Law and Social Science. Peter R. Gregware is an assistant professor of criminal justice at New Mexico State University, Department of Criminal Justice. Ph.D. 1990, Arizona State University; J.D. 1973, Columbia University. Kriss A. Drass is an associate professor of criminal justice at the University of Nevada, Las Vegas. Ph.D. 1981, Indiana University.

An earlier version of this article was presented at the Annual Meeting of the Sociolegal Conference, Bristol, England, 9-11 April 1990. This research is supported by a National Science Foundation Grant, Law and Social Science Program, grant no. SES-8908456. We thank Jane Aiken, Rebecca Bordt, Penelope Canan, Rosemarie Christofolo, and Tanya Heflin for helpful comments on earlier drafts. 
advantage and point out the ways in which the changing epidemiology of AIDS in the United States limits the use of courts.

\section{INTRODUCTION}

The U.S. courts have been involved in managing social disputes related to all modern disease scares, including syphilis, cholera, polio, bubonic plague, tuberculosis, hepatitis, and genital herpes. This project investigates how courts act upon the disputes emerging in society over Acquired Immune Deficiency Syndrome (AIDS) ${ }^{1}$ and uncovers the sociolegal justifications these institutions use to undergird their decisions.

Because of the social disorder they engender, disease scares may serve as "natural sampling devices" for revealing clearly those processes that are more hidden during normal social discourse." Social inquiry into epidemics has revealed a good deal about how cultural and social control processes work to (re)legitimate dominant institutional arrangements and prevailing norms. ${ }^{3}$ For example, Nelkin and Gilman link the process of blaming the poor or outsiders for epidemics to the preservation of power relationships and social norms seemingly threatened when marginalized groups press expansive social claims. ${ }^{4}$

At the same time, social inquiry into disease scares reveals the dynamics of a more unusual process, wherein the social standing and material conditions of disadvantaged populations are improved amid crisis. For example, Goudsblom reports that organized attempts to fight disease scares open up networks of communication and forge ties of interdependence between marginalized and dominant subcultures. ${ }^{5}$ Focusing on the polio scare of the 1940s, Cohen establishes that fear was abated, in part, when unaffected parties formed an organization, the March of Dimes, to demon-

1. For an overview of the epidemiology of AIDS, see William Heyward \& James Curran, "The Epidemiology of AIDS in the U.S.," 259 Sci. Am. 72 (1988); Jonathan Mann, James Chin, Peter Piot, \& Thomas Quinn, "The International Epidemiology of AIDS," 259 Sci. Am. 82 (1988).

2. Charles Rosenberg, "The Definition and Control of Disease-An Introduction," 55 Soc. Res. 327 (1988).

3. E.g., see Edward Albert, "lllness and Deviance: The Response of the Press to AIDS," in Douglas Feldman \& Thomas Johnson, eds., The Social Dimensions of AIDS 163 (New York: Praeger, 1986); Allan Brandt, "A Historical Perspective," in Dalton et al., AIDS and the Law 37 (New Haven, Conn.: Yale University Press, 1987) ("Dalton et al, AIDS"); Allen Brandt, "AIDS and Metaphor: Toward the Social Meaning of Epidemic Disease," 55 Soc. Res. 413 (1988); Loretta Kopelman, "The Punishment Concept of Disease," in Christine Pierce \& Donald Van de Veer, eds., AIDS, Ethics and Public Policy 49 (Belmont, Cal.: Wadsworth, 1988) ("Pierce \& Van de Veer, AIDS"); Paul Slack, "Responses to Plague in Early Modern Europe: The Implications of Public Health," 55 Soc. Res. 433 (1988).

4. Dorothy Nelkin \& Sander Gilman, "Placing Blame for Devastating Disease," 55 Soc. Res. 361 (1988). (1986).

5. Johan Goudsblom, "Public Health and the Civilizing Process," 64 Milbank Q. 161 
strate compassion for and an alliance with affected parties. ${ }^{6}$ This alliance "civilized" health care in the United States by building broad-based temporary support for socialized medicine.

We draw on the theme that disease scares serve as natural sampling devices for studying in the raw both legitimating and transformative politics and link this notion to parallel themes, evident in sociolegal thought, that address directly the dual roles of law in society. Applying these notions to our subject, we postulate that courts operate normally to depoliticize social tensions revealed by AIDs, legitimating the routines of dominant parties in the AIDS sociolegal network. At the same time, courts deviate from their normal practices by upholding the expansionary claims of subordinate parties.

Our analysis of 36 AIDs-related court rulings, published during the formative years of AIDS-related litigation (1983-87), supports the theme that courts both mirror and refract the social order in their management of disputes. We find that dominant parties bring forward claims seeking to retain their established practices as well as to utilize regulation and other control measures at their disposal to manage the social dynamics of AIDs. Courts routinely uphold these claims, particularly when they are juxtaposed to the expansionary claims of subordinate parties in the AIDS sociolegal network, specifically, persons living with HIV/AIDS (PWAS) ${ }^{7}$ and those identified as members of "risk groups." 8 At the same time, we uncover cases in which litigious subordinate parties have their expansionary claims affirmed by the courts.

To explain the duality of judicial decision making, we employ the

6. Victor Cohen, Four Billion Dimes (Minneapolis: Minneapolis Morning Press, 1955).

7. We are using the shorthand "PWAs" to include all persons who are HIV positive, and all persons who are HIV positive and living with the full spectrum of life-threatening conditions that often accompany HIV infection. The formal definition of AIDS is increasingly the source of disputes, involving the Federal Centers for Disease Control, local and state health officials, and a wide range of groups including the American Medical Association and ACT-UP. However, these disputes are more recent than the period of controversy that is the focus of this study. For a summary of the current disputes revolving around the definition of AIDS, see Mireya Navarro, "Dated AIDS Definition Keeps Benefits from Many Patients," N.Y. Times, 8 July 1991, at A1, A5; id., "US Widens Rule on Who Has AIDS," N.Y. Times, 8 Aug. 1991, at A12.

8. "Risk group" is an epidemiological concept. When connected to AIDS, it became a linguistic device for stereotyping and stigmatizing people seen as ourside the boundaries of the "general population." Pressure from activist organizations like ACT-UP led public health officials to replace "risk group" with "risk practice," which refers to the purposive activities associated with transmission of the HIV virus, namely, the sharing of needles and syringes among intravenous drug users and "unprotected" penetrative vaginal and anal sex. "Routes of transmission" is being used increasingly to capture the full range of ways that individuals may contract the HIV virus. While including "purposive" activities, it refers as well to institutional routes of contracting the HIV virus, including infection through blood transfusion. For an overview of the linguistic devices employed to signal transmission of HIV, see Jan Grover, "AIDS: Keywords," in Douglas Crimp, ed., AIDS: Cultural Analysis: Cultural Activism 17 (Cambridge, Mass.: MIT Press, 1988). 
qualitative comparative method developed by Ragin and Drass. ${ }^{9}$ This approach uses Boolean algebra to model the qualitative holistic nature of decision making by identifying the core combinations of relational and interpretational attributes or sociolegal justifications judges use to undergird their decisions. The qualitative comparative method of analysis is a quite appropriate analytic technique for the study of case-based decision making, especially if one assumes that such processes are driven by an interactive cluster of dimensions where context can change the meaning and value of any given dimension. The method has been applied successfully to the study of case-based decision making by probation officers. ${ }^{10}$ However, our research represents the first application of this method to understand the judicial management of disputes.

With the aid of the qualitative comparative method, we first trace how relational attributes, evident in the characteristics of contestants (e.g., plaintiff/defendant, status differentials) and the nature of their claims (restrictive/expansive), combine in various ways to account for wins for dominant parties, and how other combinations of these attributes define wins for subordinate parties. A second application of this method focuses on how judges combine interpretational attributes specific in the text of their rulings (e.g., cultural subjectivity in referencing divisive AIDs metaphors, deference to medical authority) to justify wins for each set of parties. Finally, in an extension of the qualitative comparative approach, we present and discuss specific court cases that contain the core configurations of attributes associated with each outcome. This provides additional context for the Boolean results and helps deepen our an:alysis and understanding of judicial management of AIDS disputes.

\section{SOCIOLEGAL AND HISTORICAL FOUNDATIONS}

Our analysis of how the courts manage AIDs disputes is grounded in strands of sociolegal thought rather than in a doctrinal approach ${ }^{11}$ to the

9. Charles Ragin, Susan Mayer, \& Kriss Drass, "Assessing Discrimination: A Boolean Approach," 49 Am. Soc. Rev. 221 (1984); Charles Ragin, The Comparative Method: Moving Beyond Qualitative and Quantitative Methods (Berkeley: University of California Press, 1987) ("Ragin, Comparative Method"); Kriss Drass \& J. William Spencer, "Accounting for Presentencing Recommendations: Typologies and Probation Officers' Theory of Office," 34 Soc. Probs. 277 (1987); Kriss Drass \& Charles Ragin, QCA: Qualitative Comparative Analysis (Evanston, Ill.: Northwestern University, Center for Urban Affairs, 1989) (Drass \& Ragin, QCA").

10. Drass \& Spencer, 34 Soc. Probs. 277 (cited in note 9).

11. For those interested in doctrinal analyses of AIDS litigation, see Gary Lawson, "AIDS, Astrology and Arline: Towards a Causal Interpretation of 504," 17 Hofstra L. Rev. 237 (1989); "Symposium on AIDS, and the Rights and Obligations of Health Care Workers," 48 U. Md. L Rev. 1 (1989); Michael Curran, "Mandatory Testing of Public Employees for HIV: The 4th Amendment's Medical Reasonableness," 90 Colum. L. Rev. 720 (1990). 
study of judicial decision making. While recognizing that the judiciary employs a distinct language as a defining attribute of its organizational culture, these strands of scholarship advance the notion that decisions are contextually driven and undergirded by social, cultural, and political judgments. ${ }^{12}$ Under this view, courts are seen as political institutions and judges as political actors. ${ }^{13}$ History more than doctrine provides the contextual basis for shaping such judgments. ${ }^{14}$ At the same time, this approach holds that judgments are made by human actors who weigh the interests of their organizations and have their own political perspectives, hopes, fears, and experiences to draw on. Thus, history guides rather than determines judgments.

Applying this perspective to what we know about how the judiciary has responded to disease scares gives us a framework for analyzing how the courts manage AIDS disputes. We organize a summary of these strands of thought and the relevant history around the principal theme that emerged from our review of these literatures: Law operates routinely to reproduce the social order and occasionally to refract that order.

\section{Law and the Reproduction of the Social Order}

A central tenet of sociolegal scholarship is that legal and social practices are reciprocally constituted and that law operates routinely to control or reproduce the social order. ${ }^{15}$ This study builds on this perspective, particularly those strands of legal pluralist thought that concentrate on the relative advantages of parties associated with claims and counterclaims ${ }^{16}$ and the relationships between different forms of law. ${ }^{17}$ We also draw on critical legal studies (CLS), which stresses the ideological base of the social hierarchy that is encoded in legal determinations. ${ }^{18}$ Finally, we show that

12. For an overview of this general perspective, see David Kairys, "Introduction," in David Kairys, ed., The Politics of Law: A Progressive Critique 1 (New York: Pantheon, 1982) ("Kairys, Polities").

13. David Danelski, "Law from a Political Perspective," 36 W. Pol. Q. 548 (1984); Austin Sarat, "The Maturation of Political Jurisprudence," 36 W. Pol. Q. 551 (1984).

14. Rogers Smith, "Political Jurisprudence, the New Institutionalism, and the Future of Public Law," 82 Am. Pol. Sci. Rev. 89 (1988).

15. Sarat, 36 W. Pol Q. at 553 (cited in note 13).

16. Marc Galanter, "Why the 'Haves' Come out Ahead: Speculations on the Limits of Legal Change," 9 Law \& Soc'y Rev. 95 (1974); Stanton Wheeler, Bliss Cartwright, Robert Kagan, \& Lawrence Friedman, "Do the 'Haves' Come out Ahead? Winning and Losing in State Supreme Courts, 1870-1970," 21 Law E' Soc'y Rev. 403 (1987).

17. Sally Moore, Law as Process (London: Routledge \& Kegan Paul, 1978); Peter Fitzpatrick, "Law, Plurality, and Underdevelopment," in David Sugarman, ed., Legality, Ideology, and the State 159 (London: Academic Press, 1983) ("Sugarman, Legality").

18. Robert Gordon, "Critical Legal Histories," 36 Stan. L. Rev. 57 (1984); Mark Kelman, A Guide to Critical Legal Studies (Cambridge, Mass.: Harvard University Press, 1987) ("Kelman, Guide"); Richard Fischl, "Realism about Critical Legal Studies," 41 U. Miami L. Rev. 505 (1987). 


\section{LAW AND SOCIAL INQUIRY}

the prevailing historical patterns of response to disease scares parallel the expectations we derive from these strands of sociolegal scholarship.

\section{Legal Pluralism}

In a review essay of "new" legal pluralism, Merry directs attention to the relationships between different forms of law, particularly the interactions between state law and nonstate legal orders. ${ }^{19}$ While it is difficult to establish the boundaries between legal orders and the rest of social life, legal pluralism points to semiautonomous social fields or loose socioeconomic networks, such as the community of public health officials and institutions, as markers of nonstate law.

One way that state law interacts with such social fields is to legitimate the authority of dominant institutional players operating in these fields and render their regulatory schemes immune from encroachment. ${ }^{20}$ This reasoning suggests that institutional parties in the AIDS sociolegal network, including blood banks, state correctional systems, and the public health community, press courts to legitimate their regulatory schemes and social control measures related to AIDS, and these (counter)claims are upheld routinely by the courts.

Also, legal pluralists assert, power advantages, enjoyed by parties operating within and across social fields, are sustained in the judicial processing of disputes. While holding that courts are influenced by legal rules and principles, including rights, they view the relative social advantage of one disputant over another as a key determinant of who wins in judicial contestations. $^{21}$

They anticipate that the stronger players within semiautonomous social spheres (e.g., administrators within the criminal justice system) win in contestations with weaker players (e.g., inmates, guards). When players from different semiautonomous spheres (e.g., public health vs. educational authorities) are disputing, those players whose domain routinely handles the substantive issues at stake usually win. Courts affect society by setting the authoritative boundaries of semiautonomous spheres and resolving contestations within and between these spheres.

\section{Critical Legal Studies}

CLS holds that legal principles and doctrines fail to determine judi-

19. Sally Merry, "Legal Pluralism," 22 Law $\mathcal{E}$ Soc'y Rev. 869 (1988).

20. Marc Galanter, "Justice in Many Rooms: Courts, Private Orderings, and Indigenous Law," 19 J. Legal Pluralism 1 (1981).

21. Galanter, 9 Law ES Soc'y Rev. 95; and Wheeler et al, 21 Law E Soc'y Rev. 403 (both cited in note 16). 
cial resolutions of disputes. Instead, court messages are indistinguishable from those generated by more overt political forums (e.g., legislatures) that shape and reinforce the dominant social ideology. ${ }^{22}$

The courts are active participants in shaping human consciousness in that legal doctrines and rights' principles are employed to uphold a set of dominant social norms (e.g., corporate profit as a social good) and social arrangements (e.g., for-profit health care system) as natural and just. ${ }^{23} \mathrm{Ad}$ ditionally, by privileging or legitimating dominant norms, legal doctrines and principles shape human consciousness by limiting awareness of polar alternatives (e.g., equality of health care as a human right).

Therefore, courts will invoke various formulations of rights regarding AIDs, but these principles will not determine outcomes. Rather, dominant social norms are encoded in the decision ${ }^{24}$ that shape societal consciousness about the disease and appropriate responses to it. For example, corporate profiteering from AIDS will gain legitimacy, care giving will be formulated as a technical responsibility of medical professionals, and illness will be tied to individual responsibility for already stigmatized populations. Norms about excessive profiteering or community engagement in health care will be silenced by the invocation of particular notions about the social good and responsibility.

CLS suggests that courts frame new problems such as AIDS in a way that confirms the social ordering that legal pluralists take as their starting point. This school of sociolegal thought seeks to uncover the norms and language encoded in court rulings that mirror the ideological base of the social hierarchy.

Researchers studying the social ecology of AIDs from the perspective of stigma, deviance, and language games offer direction for uncovering the norms and language embedded in relevant court cases that may reveal judicial reproduction of the social order. One group of scholars focuses on how the association of AIDS with stigmatized populations (e.g., sex workers, IV drug users, gay men) shapes perceptions that the illness is a product of individual responsibility and diminishes the likelihood of benevolent social responses. ${ }^{25}$ Others have analyzed how social perceptions and responses have shifted on the reporting of "innocent" or nonstigmatized persons with AIDs, including young children, hemophiliacs, and popular public figures. ${ }^{26}$

22. Fischl, 41 U. Miami L Rev. 505 (cited in note 18); Mark Tushnet, "Critical Legal Studies and Constitutional Law: An Essay in Deconstruction," 36 Stan. L. Rev. 623 (1984); Roberto Unger, The Critical Legal Studies Movement (Cambridge, Mass.: Harvard University Press, 1986) ("Unger, Critical Legal Studies Movement").

23. Gordon, 36 Stan. L. Rev. at 101 (cited in note 18).

24. Kelman, Guide 258 (cited in note 18).

25. Kopelman, "The Punishment Concept of Disease" at 49 (cited in note 3).

26. David Kirp, Learning by Heart: AIDS and Schoolchildren in America's Communities (New Brunswick, N.J.: Rutgers University Press, 1989). 
Based on these studies, we trace the success rates of individual court disputants with AIDS who come from stigmatized populations and those who enjoy full social standing. We also investigate whether institutional disputants (e.g., insurance companies, blood banks, state correctional authorities) normally litigate against individual parties with compounded social status disadvantages (e.g., gay man living with HIV/AIDs).

Studies that focus on the everyday language employed in society to give meaning to AIDS suggest that figurative speech may reveal cultural bias in judicial rulings. ${ }^{27}$ To structure our textual reading of court decisions, we focus on Ross, who identifies five metaphors (punishment, death, crime, war, otherness) that tend to encourage cultural isolation of PWAs. ${ }^{28}$ We anticipate extensive use of these divisive metaphors in the text of judicial rulings that uphold the claims of dominant players in the AIDS sociolegal network.

\section{Historical Patterns}

Historically, disease scares have revealed social and cultural tensions less evident in normal social discourse. Individual and organizational responses to the fear generated by disease scares were typically directed at preserving existing social institutions, power relationships, and social norms. For example, the syphilis scare of the late 1800 s was associated with debauched sexuality. The threat to sexual purity resulted in religious opposition to the commercially manufactured rubber condom as a practical means of combating syphilis because it "prevented debauched individuals from suffering a disease that was their necessity and certain punishment for deviating from social mores." 29

The fear generated by disease scares caused blame to be assigned to marginalized groups viewed as a threat to the established order. Assigning blame to such groups or outsiders usually resulted in the enactment of repressive social control measures and severe restrictions on civil liberties. ${ }^{30}$ For example, a mass program of detention and isolation of street sex workers was a major policy response to the venereal disease scare of World War I. State public health officials routinely detained female sex workers, subjecting them to physical examinations and quarantining them

27. Susan Sontag, AIDS and Its Metaphors (New York: Farrar, Straus, Giroux, 1989).

28. Judith Ross, "Ethics and Language of AIDS," in Pierce \& Van de Veer, AIDS 39 (cited in note 3) ("Ross, 'Ethics and Language of AIDS" "). She claims that these metaphors are dangerously divisive and carry underlying moral judgments that are shaped by and further shape perceptions. According to Ross, the most pervasive metaphor is "otherness" because it signifies a divided community. Thus, "risk groups" are separated from "our general public," and the "plague" of AIDS is seen as happening to those beyond the borders of our inclusive frameworks.

29. Nelkin \& Gilman, 55 Soc. Res. at 369 (cited in note 4).

30. Slack, 55 Soc. Res. at 435 (cited in note 3). 
on the grounds that they were "prostitutes." 31 At the height of this program, more than 30,000 sex workers were incarcerated. While the policy showed no impact on venereal disease rates and many sex workers were uninfected, state authorities continued to hold these women because they were likely to become infected. ${ }^{32}$

The historical patterns of judicial response parallel the sociolegal theme that law operates routinely to legitimate the dominant social and cultural order. In managing disputes revolving around disease scares, the courts rarely challenged cultural bias and stigma; instead they deferred to legislative authority and to the administrative bodies that legislatures entrusted to manage disease scares.

According to Gostin, legislatures determined which measures were necessary to cope with disease and their determinations were regarded as presumptively valid by the courts. ${ }^{33}$ The doctrinal rationale for this deferential approach was known as the "rational basis" or the means-ends test, which meant that there should be a connection between the measure and the end it was meant to secure (see Jacobson v. Massachusetts). ${ }^{34}$ But, the courts left open how the "rationality" of action was to be judged. This standard was later interpreted to mean "necessary for the public health," but no concrete definition of "necessity" was formulated. Instead, social and cultural factors were decisive in shaping judicial responses.

Studies of how the courts responded to challenges to the use of quarantine strategies against sex workers found stigma at the core of judicial rationales affirming the legality of social control measures. In Ex parte Company, ${ }^{35}$ "suspect conduct and association" were seen as sufficient to justify imposition of quarantine, while evidence that women before the court were not infected with venereal disease was ignored. ${ }^{36}$ In addition, challenges to quarantine powers were rejected by the courts if women were of "infamous character." 37

\section{Law and the Refraction of the Social Order}

The prevailing control metaphor and the corresponding notion that law operates to reproduce the social order are accurate but incomplete

31. Ronald Bayer, Private Acts, Public Consequences 8 (New York: Free Press, 1989) ("Bayer, Private Acts"). 3).

32. Allen Brandt, "A Historical Perspective," in Dalton et al, AIDS 39 (cited in note

33. Larry Gostin, "Traditional Public Health Strategies," in Dalton et al, AIDS 47 (cited in note 3) ("Gostin, "Traditional Strategies' ").

34. 197 U.S. 11 (1905).

35. 139 N.E. 204 (1922).

36. Gostin, "Traditional Strategies" at 51.

37. Bayer, Private Acts 9. 
representations of sociolegal interactions. For example, Sugarman calls for the avoidance of the pessimism of legal nihilism by pointing to the "complex, double-edged and deeply fissured" qualities of legal institutions. ${ }^{38}$ Extending the logic of legal pluralism, he argues that the relative autonomy the law secures for social fields provides players within these fields with the necessary discretion to both attenuate state law and to engage in contrary acts of cooperation and altruism in alliance with weaker parties in the social order. ${ }^{39}$ In addition, strong support for the view that law plays a role in social reordering is evident in the literature on social movements and the politics of resistance. Further, the historical literature on legal responses to disease scares suggests that courts occasionally blunt social control measures, sometimes providing the impetus for social change.

\section{Politics of Resistance}

This literature gives substantial weight to human agency, the capacity of individuals to make a difference, ${ }^{40}$ and marginalized groups' abilities to organize against dominant parties, structures and ideologies. ${ }^{41}$ Clearly, AIDS does offer an opportunity for dominant institutions to increase surveillance and construct a new rhetoric of control over already stigmatized parties. At the same time, the expansion of controls "yield[s] people new possibilities for defiant action," 42 and often, individual and collective defiance includes the use of state law to resist these controls. ${ }^{43}$

Piven points to the "densely interdependent relations" of social life as a source of power for marginalized parties:

People have power, the ability to make others do what they want, when those others depend upon them. Thus feudal lords have wealth, social standing and force of arms, and peasants have none of these things. Most of the time the lords are the powerful, the peasants are the powerless, and the distributional conception of power is confirmed. But it is not only peasants who need overlords in the feu-

38. David Sugarman, "Preface," in Sugarman, Legality 2 (cited in note 17).

39. Id. at 8; David Sugarman, "Law, Economy, and the State in England, 1750-1914: Some Major Issues," in Sugarman, Legality 217.

40. Stuart Henry, "Community Justice, Capitalist Society, and Human Agency," 19 Law \& Soc'y Rev. 303 (1985).

41. Frances Piven \& Richard Cloward, Poor Peoples' Movements (New York: Pantheon, 1977); id, The New Class War (New York: Pantheon, 1982); Joel Handler, The Conditions of Discretion (New York: Russell Sage Foundation, 1986) ("Handler, Conditions of Discretion").

42. Frances Piven, "Deviant Behavior and the Remaking of the World," 28 Soc. Probs. at 506 (1981).

43. Lynn Mather \& Barbara Yngvesson, "Language, Audience, and the Transformation of Dispures," 15 Law \& Soc'y Rev. 775 (1980-81); Rebecca Bordt \& Michael Musheno, "Bureaucratic Co-optation of Informal Dispute Processing: Social Control as an Effect of Inmate Grievance Policy," 25 J. Res. Crime $\&$ Deling. 1 (1988); Sally Merry, Getting Justice, Getting Even (Chicago: University of Chicago Press, 1990). 
dal system of production; overlords need peasants. It is not only labor that needs capital in an industrial system of production; capital is not capital without labor. It is not only wives who need husbands; husbands need wives, as doctors need patients. ${ }^{44}$

Public agencies have come to understand that to research AIDS and construct paths of service delivery, they must depend on the cooperation of organized groups in the affected communities. AIDs has forced state institutions to recognize gay organizations in order to advance their organizational interests. ${ }^{45}$

In rare cases, we anticipate that courts recognize the interests at stake and act to authorize partnerships between dominant state institutions and community-based gay advocacy organizations. Such actions by institutions of conflict management serve to legitimate these organizations and enhance their standing to struggle against stigmatization. Altman refers to this process as "legitimation through disaster." 46

\section{Historical Countertendencies}

Historical studies of law and disease scares indicate these are countertendencies to judicial legitimation of dominant interests and cultural bias. As early as 1896 , judges showed an interest in medical and scientific evidence to sort out their positions regarding state measures to control disease scares. In Smith v. Emery, ${ }^{47}$ a state appellate court rejected state control measures based only on the possibility of exposure to smallpox, requiring instead that such measures have the backing of "medical science and skill." Given the growing influence of medical authority in society, ${ }^{48}$ we anticipate that deference to medical authority will be evident in the text of AIDS cases and that to effectively resist control measures, PWAs need medical expertise to bolster their claims.

$\mathrm{McClain}$ offers historical evidence that the courts have on occasion legitimated the struggles of marginalized groups seeking to improve their social standing while facing crisis brought on by a disease scare. ${ }^{49} \mathrm{He}$ provides a detailed account of the legal battles surrounding the bubonic plague scare of 1900 in San Francisco. When a few instances of bubonic plague were detected in San Francisco's Chinatown, health authorities initiated draconian control measures aimed solely at the city's Asian popula-

44. Piven, 28 Soc. Probs. at 501 (cited in note 42).

45. Dennis Altman, "Legitimation through Disaster: AIDS and the Gay Movement" (presented at the American Political Science Association Annual Meeting, Chicago, 1987).

46. Id.

47. 42 N.Y.S. $258(1896)$.

48. Michel Foucault, Discipline and Punish (New York: Vintage Books, 1979).

49. Charles McClain, "Of Medicine, Race and American Law: The Bubonic Plague Oucbreak of 1900," 13 Law \& Soc. Inquiry 447 (1988). 
tion. Well organized and adequately resourced, the Chinese community reacted strongly, challenging these measures and asserting positive claims in the federal courts. In Jew Ho v. Williamson ${ }^{50}$ and Wong Wai v. Williamson, ${ }^{51}$ the presiding judge rebuked the measures as blatantly discriminatory against a race of people, empowered physicians selected by the organized interests of Chinatown to attend persons suspected of being afflicted with the plague, and ordered city officials to direct resources to the "cleaning" of Chinatown. This historical account suggests that marginalized people identified as disease "carriers" or "high-risk" groups require substantial organization and resources if they are to be successful in pressing expansionary claims amidst a disease scare.

\section{PROPOSITIONS, DATA, AND METHODS}

With Ams as our substantive area of focus, we seek to provide a holistic account of formal judicial processing of relevant disputes. ${ }^{52}$ To ground our interpretation in empirical evidence and establish its potential for replication, we divide our analysis into stages, offer propositions or questions relevant to each stage, and describe the data sets and analytical techniques used to address these propositions and questions.

We analyze 36 AIDS-related, court cases published from the early 1980s until the end of 1987.53 These cases are representative of the legal issues before the courts during the formative years of AIDs litigation, ${ }^{54}$ and tem-

50. 103 Fed. Rep. 10 (N.D. Cal. 1900).

51. Id.

52. This study is part of an ongoing project which recognizes that formal legal disputes capture only the "tip of the iceberg" of disputing and dispute processing in the United States. Other parts of the project focus on the earliest phases of disputing-" "naming, blaming, and claiming"; the roles of third parties and audiences in shaping the early phases of dispute processing, including outreach and caseworkers who work directly with PWAs; and the process of settlement. For a general overview of the early phases of disputing and dispute processing, see William Felstiner, Richard Abel, \& Austin Sarat, "The Emergence and Transformation of Disputes: Naming, Blaming, Claiming," 15 Law \& Soc'y Rev. 631; Mather \& Yngvesson, 15 Law \& Soc'y Rev. at 775 (cited in note 43).

53. Researchers have found that published cases may not be representative of all cases associated with a given legal issue. For this reason, we are collecting a set of unpublished cases as part of the larger project. Regarding the representativeness of published cases generally, see Peter Siegelman \& John Donohue III, "Studying the Iceberg from Its Tip: A Comparison of Published and Unpublished Employment Discrimination Cases," 24 Law \& Soc'y Rev. 1133 (1990).

54. To assure that our sample was representative of the legal issues before the courts, we were guided by the legal classification system developed by Lawrence Gostin, "The AIDS Litigation Project: A National Review of Court and Human Rights Commission Decisions," 263 J.A.M.A. 1961 (1990). Specifically, he identifies 15 legal issues with the highest incidence of court activity revolving around the following: criminal law, prisons, blood supply, and discrimination. We sorted the population of cases according to these categories and a general category labeled "other." Once sorting was completed, we eliminated only those published cases with less than one page of text. Otherwise, we selected cases randomly across the five-part classification scheme. Gostin (id. at 1961) reports that AIDS cases are 
porally they parallel the period of AIDs history in the United States in which broad consensus was reached that society faced a lethal epidemic. For this analysis, AIDS-related cases include those

1. which involve the claims of PWAs, people associated with "high-risk groups" (e.g., IV drug users, prisoners), and/or parties who are representing these people;

2. where the court specifically addresses claims of parties in situations in which the social ecology of AIDs is central to courts' decisions;

3. where the claims of the contesting parties are significantly derivative of the social ecology of AIDs.

We content analyzed and coded the 36 cases $^{55}$ to obtain discrete and textual measures of the types of claims, counterclaims, parties, and interpretational attributes embedded in the judicial rulings. Descriptive statistics are used to document the relative frequency of different types of (counter)claims and parties, as well as to examine the relationship between parties and claims and parties and win rates. Further, we used the qualitative comparative method, ${ }^{56}$ based on Boolean algebra, to identify the combinations of relational and interpretational attributes associated with wins for dominant parties and those associated with wins for subordinate parties. A detailed description of this analytic technique is presented below.

\section{Claims Generation and Judicial Responses}

As a primary institution of conflict management, the courts are called on by litigious individuals and institutional actors to bring order to the welter of competing claims generated by the social ecology of ArDs. Pwas, people identified as members of high-risk groups, and their supporters are likely to make legal claims to seek relief from discrimination and invasions

equally divided between federal and state/municipal systems. For our sample, 17 cases were federal and 19 cases were from state/municipal systems. Currently, we are coding the remaining published cases listed in Appendix A.

55. Coding was completed by three persons with legal training (Gregware and two second-year law students). The codebook, developed initially in conference by a larger research team that included the coders, was adjusted by the coders who often met as a subgroup as they moved iteratively between codebook and test cases. Adjustments in operational definitions of variables were arrived at through consensus, and when no consensus could be reached, final adjustments were made through a deliberative process involving the larger research team. Next, 10 written decisions were initially coded by each coder and their results were compared. If all three coders agreed in 9 of 10 cases, then the operational definition of a variable was considered reliable and the remaining cases were coded by a single coder. The remaining variables were coded by at least two coders, and any discrepancies were resolved by discussion and the employment of a consensus rule among the coders. Any coding decisions unresolved by the coders were taken to the larger research team for final resolution.

56. Ragin, Comparative Method, and Drass \& Ragin, QCA (both cited in note 9). 
of privacy. ${ }^{57}$ Parties are interested in securing self-regulation as a basic tenet for coping with AlDs in society. These parties may seek compensation and resources to cope with the disease. Hemophiliacs seek compensation from blood banks, and other citizens with limited or exhausted resources seek state funds to purchase drugs available on the market, access to experimental drugs, and the right to health care. ${ }^{58}$ Together, these citizens are seeking a redistribution of resources and changes in the market-driven U.S. health care system.

We expect corporate institutions' responses to these claims to be consistent with their organizational interests and routine practices. Fundamentally, they seek to maintain established practices and distribution patterns despite the onslaught of AIDs. For example, insurance companies will seek to maximize profits by defining AIDs as outside the bounds of their responsibility, narrowly interpreting their contractual obligations to the insured and adjusting underwriting decisions. ${ }^{59}$

State institutions structure claims for those who fear contagion and seek to secure the health and safety of the uninfected public. Therefore, we anticipate that state institutions will assert (counter)claims to legitimate their regulatory schemes and social control measures. For example, criminal justice agencies increase surveillance and control measures over populations inside and outside of prison suspected of spreading the virus. ${ }^{60}$ And based on their historical domination over disease scares since the early 1900 s, the public health sphere attempts to oversee the activities of all affected parties by making demands that their regulatory schemes for addressing the disease are legitimated by the courts. ${ }^{61}$ The efforts of state institutions, in turn, are likely to elicit counterclaims for protection of liberty by those whose social mobility is to be restricted by such regulatory and control measures as involuntary testing. Each relevant party represents a social field dependent in various degrees on the actions of other parties, particularly those promulgated by the public health sphere. Together, the relevant institutional and individual parties, along with the institutions of conflict management, represent the AIDS sociolegal network. ${ }^{62}$

For this analysis, claims and counterclaims for redistribution, self-regulation, and liberty are grouped as expansionary claims. ${ }^{63} \mathrm{We}$ anticipate

57. Mark Senak, "The Lesbian and Gay Community," in Dalton et al, AIDS 290 (cited in note 3 ).

58. Taunya Banks, "The Right to Medical Treatment," in Dalton et al, AIDS 175.

59. Richard Mohr, "AIDS, Gay Men and the Insurance Industry," in Pierce \& Van de Veer, AIDS 138 (cited in note 3); Mark Scherzer, "Insurance," in Dalton et al, AIDS 185.

60. John Decker, "Prostitution as a Public Health Issue," in Dalton et al, AIDS 81.

61. Gostin, "Traditional Strategies" at 47 (cited in note 33).

62. On sociolegal networks generally, see Edward Laumann \& David Knoke, The Orga. nizational State: Social Policy in National Policy Domains (Madison: University of Wisconsin Press, 1987).

63. We infer the fundamental sociolegal claim of each party or the (counter)demand that prompted the dispute for each player regardless of whether the court's opinion overtly 
that PWAs, persons viewed as members of high-risk groups, and their support groups are most likely to bring forward such claims. As subordinate parties in the AIDS sociolegal network, these parties, like subordinate parties in other networks, are most likely to initiate court action as a way to bolster their standing against dominant, institutional parties.

Claims seeking to sustain regulatory schemes and social control measures, as well as those calling for the maintenance of established practices and distributional patterns, are grouped as restrictive claims. We anticipate that these claims will come from institutional players. While we expect both institutional players and persons with AIDS to initiate court action, we anticipate a greater use of the courts by subordinate parties because they have less to lose than those parties with superior social standing in the evolving AIDS network. Finally, we expect institutional players to be selective in initiating contestations with individual parties, picking adversaries who are least likely to gain the sympathy of the courts. Therefore, they are likely to initiate actions against individual parties with compounded social status disadvantages (e.g., PWAs who are IV drug users) more often than against parties whose status disadvantage is AIDS specific (e.g., hemophiliacs living with HIV/AIDs).

In addition to using the legal characterization of parties (plaintiff/defendant), we build on the work of Galanter ${ }^{64}$ and Wheeler et al ${ }^{65}$ to determine which, if either, of the two parties has superior social standing relative to each case. We use two indicators-whether either party has superior resources due to their size ${ }^{66}$ and whether either party has a role advantage ${ }^{67}$ in the AIDS sociolegal network-to identify the dominant and subordinate party in each of the 36 court contestations. The two indica-

deals with the substance or the social significance of the dispute. To draw this inference, we code the basic facts of the case in textual form; categorize the domain of the dispute (i.e., governmental process, business, torts, criminal process, family process); and categorize and give textual reference to the legal claim asserted by each party (e.g., housing discrimination; gay life partner of deceased person with AIDS should be able to take over apartment lease). Referencing these items, guided initially by operational definitions abstracted from the discussion of claims above and modified by the coders as they moved iteratively between operational definitions and test cases, coders recorded the fundamental sociolegal claim of each party as "maintenance" of established practices and distributional patterns; "redistribution" of resources and status, and/or a break from established decision-making patterns; "regulation" of (potentially) infected populations or imposition of other social control measures by state institutions; "self-regulation" at a time when there is no institutional control or seeking self-control as an alternative to the imposition of institutional control; and "liberty" or seeking to be free from state control when a state institution has acted and the party's challenge to that control is based on some notion of individual rights.

64. Galanter, 9 Law E Soc'y Rev. 95 (cited in note 16).

65. Wheeler et al, 21 Law \& Soc'y Rev. 403 (cited in note 16).

66. For example, a federal governmental agency or a major corporation would have superior resources relative to a community school board or a local hospital.

67. Role advantage involves situations in which one party has coercive powers over the other, such as regulator/regulatee or correctional administrator/inmate. It also includes relative difference in social authority, such as doctor/patient. 
tors are highly intercorrelated and provide a nominal-level distinction between parties comparable to Galanter's one-shot versus repeat player classification of contesting parties. ${ }^{68}$

Bringing together the types of claims with the legal and social characterization of parties, we anticipate the following:

P1: Dominant parties are more likely to bring forward restrictive claims while subordinate parties are more likely to bring forward expansive claims;

P2: Subordinate parties initiate court action more often than do dominant parties;

P3: Dominant parties are more likely to initiate court action against individual parties with compounded social status disadvantages than against individual parties who are living with HIV/AIDs but who otherwise enjoy community standing.

Regarding judicial responses to these claims, we postulate the following:

P4: Dominant plaintiffs engaged in formal legal contestations are routine winners while subordinate plaintiffs have a much lower win rate, even though they litigate more often.

\section{Explaining Judicial Rulings}

In addition to the basic questions of who litigates, who wins, and under what circumstances different parties win, we are also interested in discovering how relational attributes affect court decisions and how judges use different sociolegal rationales to account for their decisions. To explore these issues, we use the method of qualitative comparative analysis based on Boolean algebra, the algebra of logic and set theory. ${ }^{69}$ We chose this approach because it has certain advantages over traditional statistical techniques, and several of these advantages are particularly relevant for our data. ${ }^{70}$

First, qualitative comparative analysis is holistic. Unlike most statistical techniques, it does not assume that the effect of an explanatory variable is the same regardless of the values of other variables. Rather, qualitative comparative analysis assumes that variables exert their influence in combination with other variables and tries to identify which combinations are crucial for distinguishing one outcome from another. We believe that this approach more closely approximates the nature of legal decision making in which combinations of attributes are weighed within the context of a particular case.

68. Galanter, 9 Law $\mathcal{E}$ Soc'y Rev. ar 97-114 (cited in note 16).

69. Ragin, Comparative Method, and Drass \& Ragin, QCA (both cited in note 9).

70. Charles Ragin, "The Logic of the Comparative Method and the Algebra of Logic," 1 J. Quantitative Anthropology 373 (1989). 
A second advantage of qualitative comparative analysis is that it is much less sensitive to sample size than traditional statistical analysis. It is possible to conduct a holistic analysis statistically by computing and analyzing interaction effects (e.g., with multiple regression or a hierarchical log-linear model). However, because of their distributional assumptions, these models generally require a fairly large number of cases in order to obtain an acceptable number (usually five) for each interaction (i.e., each combination of explanatory variables). Because of its reliance on Boolean algebra (as opposed to linear algebra), and because it focuses on differences in type rather than number, qualitative comparative analysis can safely perform holistic analysis even with relatively small samples. ${ }^{71}$

A final advantage of qualitative comparative analysis for our research is its sensitivity to the potential importance of deviating cases. ${ }^{72}$ Because the cases we examine are among the first to confront the courts regarding AIDS, we must be sensitive to the possibility that stable routines for handling these cases have not yet emerged. Therefore, while it is certainly important to look for patterns among the combinations of attributes associated with different outcomes, we must also try to explain all cases, even those that deviate from the patterns. These unique cases may in fact represent important instances in which the social order is refracted rather than simply reflected. Statistical analysis, with an emphasis on central tendency, is more likely to treat such deviation as error (and, may actually be adversely affected depending upon the degree to which cases are different). Qualitative comparative analysis, on the other hand, is comfortable with multiple explanations for outcomes and simply treats deviations in this manner.

Qualitative comparative analysis uses systematic and logical case comparisons based on the rules of Boolean algebra to identify the combinations of explanatory variables that are unique to an outcome value and, thus, are crucial for distinguishing that outcome value from all others. Since Boolean algebra permits only two values ( 0 and 1$)$, all variables must be dichotomous; generally, 0 is used to indicate the absence of an attribute and 1 is used to indicate the presence of an attribute. Because comparisons are qualitative, looking for presence or absence of attributes, they are not sensitive to the frequency distributions of explanatory or outcome variables.

The starting point for a qualitative comparative analysis is the construction of a truth table. A truth table lists all the unique combinations of explanatory variables appearing in a data set, along with the corresponding value of the outcome variable for each combination. Consistent with an emphasis on qualitative diversity, rather than frequency, each

71. Id. at 376-77.

72. Id. at 375 . 
combination appears only once in the truth table regardless of how often it appears in the data. Thus, a truth table summarizes the range of diversity in a data set (in terms of the combinations of values of the explanatory variables) and establishes links between these configurations and values of the outcome variable. As an example, we present a hypothetical truth table in table 1.

Table 1 represents a truth table with three explanatory variables for

\section{TABLE 1}

Hypothetical Truth Table: Three Explanatory Attributes $(\mathrm{O}=$ No; $1=$ Yes)

\begin{tabular}{ccccc}
\hline Row & $\begin{array}{c}\text { Winner Is } \\
\text { Plaintiff }\end{array}$ & $\begin{array}{c}\text { Winner Has } \\
\text { Higher } \\
\text { Social Status }\end{array}$ & $\begin{array}{c}\text { Winners Demand } \\
\text { Is Restrictive }\end{array}$ & $\begin{array}{c}\text { Outcome: } \\
\text { Dominant } \\
\text { Party Wins }\end{array}$ \\
\hline 1 & 0 & 0 & 0 & 0 \\
2 & 0 & 0 & 1 & 0 \\
3 & 0 & 1 & 0 & 0 \\
4 & 0 & 1 & 1 & 1 \\
5 & 1 & 1 & 1 & 1 \\
6 & 1 & 1 & 0 & 1 \\
7 & 1 & 0 & 1 & 0 \\
8 & 1 & 0 & 0 & 0 \\
\hline
\end{tabular}

dominant party winning. In the table 0 s represent the absence of an attribute and the expected outcome while 1s symbolize the presence of the attribute and the expected outcome-dominant parties winning. With three explanatory variables, there are eight possible combinations of attributes that may exist in the data. Rows 4,5 , and 6 show hypothetical combinations of attributes that are unique to wins for dominant parties. For example, row 4 indicates that dominant parties win when they have higher social status and are pressing a restrictive demand.

After constructing a truth table, the next step involves simplification of rows in the truth table using minimization algorithms from Boolean algebra. The goal of this simplification process is to reduce the complexity of a truth table by looking for "irrelevant" variables within configurations-irrelevant in the sense of being unnecessary for differentiating one outcome value from another. Once found, these variables can be eliminated. This logic of simplification can be summarized as follows:

If two combinations are identical in value for every attribute but one, then the two combinations can be combined into one configuration with that variable deleted. ${ }^{73}$

73. Drass \& Spencer, 34 Soc. Probs. at 287 (cited in note 9). 
This principle ${ }^{74}$ can be illustrated by looking at rows 4 and 5 of table 1 . These rows show that dominant parties win when they enjoy higher social status and bring forward restrictive demands regardless of their legal status as plaintiff or defendant. With legal status irrelevant for this combination, one simpler combination with attributes (-11, where "-" means "either 0 or 1") can replace two more complex rows in the truth table (rows 4 and 5 in our example). The simpler configuration $(-11)$ logically implies the more complex ones and can replace them without loss of significant information. The purpose of a qualitative comparative analysis is to constantly apply this comparative logic until no more reductions in the truth table are possible. The final results provide two important kinds of information:

1. The simplified configurations summarize the core combinations of [explanatory attributes] that are always associated with the specified value of the [decisional outcome];

2. The simplified configurations also summarize the unique ways in which [explanatory attributes] combine for this value of the [decision outcome].

\section{Relational Configurations}

Using this approach, we trace how relational attributes, evident in the social and legal characteristics of contestants (e.g., plaintiff/defendant; status differentials), and the nature of their claims, combine in various ways to define wins for dominant parties, and how other combinations of these attributes account for wins for subordinate parties. Specifically, we code: 1. The legal attributes of parties (plaintiff/defendant)

2. Whether either party had a social or cultural status advantage over the other due to a composite of stigmatizing characteristics ${ }^{75}$

3. Whether either party had discretion to vacate the relationship as is typical in market relationships ${ }^{76}$

74. Technically, truth table reduction is accomplished through the use of minimization algorithms originally developed by electrical engineers for the simplification of switching circuits. The general goal of Boolean minimization is to reduce the complexity of a truth table by finding the smallest set of reduced configurations that logically imply all the original rows of a truth table with a particular outcome value. The specific algorithm that we used in this analysis is the classic Quinn-McCluskey algorithm, as implemented in the software developed by Drass \& Ragin, QCA (cited in note 9). It is important to emphasize that these algorithms employ an abstract logic of holistic simplification that is completely compatible with a social-scientific interest in how context shapes decisions. Entire rows are compared one to another, and explanatory variables are considered relevant or irrelevant only within the context of specific combinations of other variables.

75. For the plaintiff and the defendant, we coded whether or not the respective party was: a PWA; gay; an IV drug user, a criminally convicted person and/or a prisoner. Advantage was determined relative to the competing parties in each case.

76. If there is an ongoing relationship between the parties in a given case, we coded 
4. The claim brought by parties (restrictive/expansive) ${ }^{77}$

\section{Interpretational Configurations}

Our second application of qualitative comparative analysis focuses on the sociolegal logic undergirding judicial decisions. Here, we trace how interpretational attributes, embedded in the text of judicial rulings (e.g., use of divisive AIDS metaphors), combine in various ways to legitimate wins for each set of parties. The text of the decisions were analyzed for the following characteristics:

1. The presence or absence of divisive AIDS metaphors while taking into account situations in which judges dispel them ${ }^{78}$

2. The presence or absence of traditional and nontraditional legal presuppositions, such as adherence to the rule versus adjustment to the situation ${ }^{79}$

whether the parties had discretion to vacate the relationship. Parties in a landlord/tenant relationship have substantial discretion to vacate the relationship, while parties in a prison guard/inmate relationship have little discretion to terminate their interactions. Generally, market relationships allow more discretion than relationships involving coercive state powers.

77. For details on the coding of claims see note 63.

78. We drew on the metaphor scheme developed by Ross, "Ethics and Language in AIDS," at 39 (cited in note 28), using the following metaphors and respective indicators to identify their use in the text of written decisions: death (e.g., AIDS personifies death, AIDS is looking for victims, AIDS is inevitably a killer); punishment (e.g., a violation of God's law, retribution for wrongdoing); crime (e.g., victim of . . ., AIDS is a serial killer, terrorizing victims); war (invaders, enemy, body count, time bomb); otherness (threatens health of the general public, inner-city problem, problem of risk groups, what we must do about them). If a coder determined that one or more of the metaphors was present in a given case, (s)he would record the presence of each metaphor and the text in which the metaphor was embedded. For each metaphor spotted, the coder would record whether the court sought to negate the bias implied by the respective metaphor.

Additionally, AIDS metaphors were often used repeatedly and with variation within a metaphor category. For example, in reference to the war metaphor, one judge used phrases like "subject to the onslaught," "inferno," and "it begins to attack," to describe AIDS-see Ray v. School Dist. of Desoto County, 666 F. Supp. 1524 (M.D. Fla. 1987). In another case, multiple examples of the punishment metaphor are used by a judge, including the phrases "no sentence can compare with the pain of AIDS" and "disease processes have . . . condemned to death"- -see People v. Camargo, 516 N.Y.S.2d 1004 (1986). Also, judges sometimes combine metaphors, such as the crime and death metaphors in "lethal infectious killer" when discussing AIDS-see Dist. 27 Community School v. Board of Educ., 502 N.Y.S.2d 325 (1986). To fit our measure to context, we coded AIDS metaphors as absent if the judge tried to dispel the divisiveness that AIDS metaphors engender. For example, in Broadway Books v. Roberts, 642 F. Supp. 486 (E.D. Tenn. 1986), the judge dispelled the war metaphor by saying, "Our skies are not black with smoke from cities burned to prevent the spread of plague."

79. To systematically analyze whether and how legal presuppositions are embedded in the text of rulings, we began with the paired contradictory premises outlined by Kelman, Guide 258 (cited in note 18), who conceptualizes "deeply embedded, structural premises that clearly enable decision makers to resolve particular controversies in opposite ways." $\mathrm{He}$ distinguishes "core privileged liberal values" (i.e., rule-bounded legality, individualism, value subjectivity, intentionalism, nonpaternalism) from "dissident ones" (i.e., situation-sensitive 


\section{Whether the court defers to medical authority in reaching a judgment ${ }^{80}$}

4. Whether the court acknowledges possible applicability of rights by citing them, and whether such rights are used as a basis for the decision ${ }^{81}$

standards, altruism, value objectivity, determinism, paternalism). Drawing on Kelman's extensive discussion of each set of paired opposites (e.g., intentionalistic vs. determinalistic discourse, at 3,86 ), we developed operational definitions for each premise and moved iteratively between definitions and test cases to refine our indicators. The two coders nor involved in this process were exposed to the refined operational definitions (along with background readings) and given test cases to code. These stages of preliminary work resulted in the following coding scheme. "Traditional" legal presuppositions include rulebounded legality (i.e., follow the rule); individualism (i.e., pursue individual ends as long as doing so respects the ends of others); intentionalism (i.e., individuals are responsible for their behavior); supremacy of reason (i.e., feelings or desires are suspect and should not be used to justify actions-rely only on reason or objective, intellectual process). As paired opposites, "nontraditional" legal presuppositions include adjustment to the situation (i.e., context is more important than the rule); altruism (i.e., the other as important as self); determinism (i.e., social and cultural conditions shape individual behavior); and privileging of desires/emotive needs (i.e., emotional bonds and expressions of feelings have standing).

For each legal presupposition, the coder recorded its presence or absence in a given case, and provided the textual basis for reaching such a conclusion. Some examples of traditional legal presuppositions are as follows: for rule-bounded legality, "we think it is our duty to adhere to the rule" (Blair v. United States, 525 A.2d 170 (D.C. App. 1987)); for individualism, requiring children living with HIV to be "responsible" for their behavior while at school (Ray v. School Dist. of Desoto County, 666 F. Supp. 1524 (M.D. Fla. 1987)); for intentionalism, in citing that "staff had actual knowledge of high risk sexual activity ... and chose to condone it" (City of New York v. New St. Mark's Baths, 497 N.Y.S.2d 979 (1986)); for supremacy of reason, seeing the court relative to the jury as an "unbiased, uninfluenced adjudicator" without "prejudice" (Blair v. United States 525 A.2d).

Some examples of nontraditional legal presuppositions are for adjustment to the situation, where the court asserted that decisions should be reached for each child on a case by case basis and explored "matters not strictly relevant to this one child" (Dist. 27 Comm. School v. Board of Educ., 502 N.Y.S.2d 325 (1986)); for altruism, where the court, rather than following the rule, relied on "compassion" (People v. Camargo, 516 N.Y.S.2d 1004 (1986)); for determinism, where the court found that individuals acquired AlDS "through no fault of their own" Ray, 666 F. Supp.); for privileging desires/needs, where the court gave "weight" to the emotional bond between two individuals (Yorkshire Towers Co. v. Harpster, 510 N.Y.S.2d 976 (1986)).

80. For each case, coders recorded whether medical evidence was cited and whether the court "deferred" to medical authority in reaching a decision. When medical evidence was cited and when it was identified as authoritative, the coder noted the appropriate textual reference(s). For our purposes, deferring to medical authority was operationally defined as follows: the court states explicitly that its decision is based, all or in part, on the evidence provided by medical/scientific experts. Courts deferred to medical authority in 14 cases and when upholding the claims of both dominant and subordinate parties. For example, in Broadway Books v. Roberts, 642 F. Supp. 486 (E.D. Tenn. 1986), the testimony of a public health physician, stating that one could potentially contract HIV from blood and semen on the walls of peep show booths, provided evidence of a "hazard" substantial enough for the court to allow governmental intervention. In Kentucky Central Life Insurance Co. v. Webster, 651 F. Supp. 935 (N.D. Ala. 1986), the court cited medical evidence to conclude that a PWA made a valid application for insurance, and thus was entitled to coverage.

81. For each case, coders recorded "rights" as present when the court makes reference to any federal or state constitutional provision as well as any civil rights specifically created by legislative enactment. A right was recorded as "deferred to" when the court makes explicit reference to a right and states that it is granting a claim based on that explicit reference. The actual constitutional provision and/or legislative statute was recorded when a 


\section{FINDINGS}

Guided by the three propositions identified above (P1-P3), we turn initially to the relationship between parties and claims. We then analyze the win ratios of dominant and subordinate parties with the expectation that dominant parties are routine winners (P4). Turning to the qualitative comparative analysis, we look at the relational configurations that account for wins for dominant parties, and for subordinate parties. Finally, we present the interpretational configurations which rationalize wins for dominant parties and those evident when subordinate parties win.

\section{Parties and Claims}

As initiators of claims, plaintiffs set the tone of court contestations. We find plaintiff claims generating 17 restrictive claims and 19 expansive claims. When we isolate dominant plaintiffs, we find these plaintiffs engaged in 14 of the 36 cases, bringing forward restrictive claims in every case. Further, in every one of these cases, defendants are subordinate parties pressing expansive counterclaims.

Who are these dominant plaintiffs? Who do they litigate against? What specific claims are they bringing to the courts? Three cases typify conflict generation under these conditions. In New St. Mark's Baths, ${ }^{82}$ the local public health authority used new regulatory authority to close a bathhouse and the owners countered with a liberty claim, seeking to extend privacy guarantees regarding sexual activity to commercial establishments. Yorkshire Towers Company ${ }^{83}$ involves a landlord seeking to evict a male from an apartment who had a long-standing "quasi-marital relationship" with the male leaseholder who died of AIDs. The occupant countered with an expansive claim to extend marital protections to long-standing relationships between partners of the same sex. In Haywood County v. Hudson, ${ }^{84}$ county jail and health officials sought and received local court backing to maintain their discretionary authority over those in custody to draw blood from a detainee for an AIDS antibody test. The detainee countered by asking that the protections surrounding the self-regulation of religious practices be extended to prevent involuntary testing.

We find additional support for our proposition that a party's standing in the AIDS network, more than the legal classification of parties, defines the structure of demands (see P1 above). Isolating those cases in which the

coder determined that a right is evident in a case, and when the coder determined that a right was used as a basis for a decision.

82. 497 N.Y.S.2d 979 (1986).

83. 510 N.Y.S.2d 976 (1986).

84. 740 S.W.2d 718 (Tenn. 1987). 
plaintiffs are subordinate parties, we find those players bringing forward expansive claims in 18 of these 22 cases. In all 18 cases, the defendant is dominant in the AIDS network relative to the plaintiff and is attempting to impose a restrictive (counter)claim.

One set of cases involve contestations within semiautonomous spheres of the AIDS network as typified by Board of Education, Plainfield $v$. Cooperman. ${ }^{85}$ Here, the plaintiff, a local school board, asserts the right of communities to self-determine whether and under what conditions, children with AIDS are permitted to attend public schools. The state board of education counters, claiming that its regulatory scheme should apply to all local boards of education. A second set pits local, commercial interests as plaintiffs against public health authorities. For example, in Broadway Books v. Roberts, ${ }^{86}$ the operators of an adult bookstore assert First Amendment liberties in challenging a local public health ordinance intended to clamp down on their use of private booths for patrons where "homosexual activities" are alleged to take place. A third set involves individual parties with AIDS and other stigmatizing characteristics against state criminal justice authorities. In Doe $\%$. Coughlin, ${ }^{87}$ typical of such cases, an inmate diagnosed as having AIDS seeks to extend the federal Rehabilitation Act, prohibiting discrimination against handicapped persons, to negate special social-control measures imposed on inmates with AIDs by state correctional authorities.

Consistent with our second proposition (see P2 above), subordinate parties are the most likely to initiate court action. Specifically, subordinate parties are plaintiffs in 22 of the 36 cases. While a number of the formal disputes are initiated by dominant parties contesting other institutional players within and across semiautonomous spheres of the AIDS network, dominant parties show a greater reluctance to turn to the courts and/or have less of a need to do so. In fact, individuals are the most prevalent plaintiffs, invoking formal legal contestations in 16 of the cases. Nine of these litigants have sound social standing, four having no stigmatizing characteristics (e.g., individual business proprietor), and the remaining five are PWAs who have no other stigmatizing characteristics (e.g., hemophiliac with AIDS). The remaining seven individual plaintiffs are stigmatized persons such as a PWA who is also an IV drug user.

At the same time, we find that when dominant institutional parties do initiate a formal, legal contestation, they litigate normally against highly stigmatized individuals (see P3 above). All 12 individual defendants are highly stigmatized persons or persons without community standing who face as their opponents state and corporate institutional parties in the AIDS

85. 523 A.2d 655 (N.J. 1987).

86. 642 F. Supp. 486 (E.D. Tenn. 1986).

87. 509 N.Y.S.2d 209 (1986). 
network. The bulk of these defendants are PWAs who are criminally accused, detained, or convicted individuals in contestations with social control agencies. Thus, highly stigmatized individuals are the single most active players in AIDS-related cases under investigation.

\section{Who Wins}

While subordinate parties are more litigious than dominant parties, they have a lower win rate (see $\mathrm{P} 4$ above). In the 22 cases where subordinate parties are the plaintiffs, they win six times, producing a win rate of approximately 27 percent for the cases under investigation. Dominant plaintiffs were identified in 14 cases and they won eight times, generating a win rate of 57 percent. While consistent with our initial conceptualization, these findings suggest that subordinate plaintiffs win with some frequency. Yet, in comparison to dominant plaintiffs, they are twice as likely to bring their claims to the courts and are only half as likely to win.

Agencies of the state and citizens are the major players in the cases we analyzed, making up 81 percent of the possible parties. State agencies win 62 percent $(8 / 13)$ of its cases as a plaintiff and 69 percent $(11 / 16)$ of its cases as a defendant, while citizens win at 31 percent $(5 / 16)$ as plaintiffs and 46 percent $(6 / 13)$ as defendants. This markedly lower win rate for individual plaintiffs is highlighted when we look at PWAs and/or people identified with high-risk categories, such as prisoners; their win rate is 17 percent (2/12). If we remove the two cases that children living with HIV/ AIDS won in school segregation cases, we find that this group does not win at all. Being a PWA and/or a person without community standing seems to be a clear disadvantage for those individuals who bring AIDS-related claims forward for judicial resolution.

Some interest spheres of the AIDS sociolegal network did much better than others. For example, parties associated with the institutional interests of criminal justice won 73 percent $(11 / 15)$ of the time. Public-healthrelated parties won all four of their cases, and the health sector, public and private health, and health products businesses won 90 percent $(9 / 10)$ of the time. This compares with education and insurance/real estate spheres winning less than half their cases.

\section{Relational Attributes and Case Outcomes}

How do relational attributes affect the outcomes of AIDs cases? Table 2 presents, in the form of a truth table, the various combinations of relational attributes associated with wins (dominant party wins $=1$ ) and 


\section{TABLE 2}

Truth Table Showing Configurations of Relational Attributes

Associated with Dominant Party Wins and Losses

\begin{tabular}{|c|c|c|c|c|c|c|}
\hline \multicolumn{5}{|c|}{ Explanatory Variables $(\mathrm{O}=\mathrm{No} ; 1=\mathrm{Yes})$} & \multirow{2}{*}{$\frac{\text { Outcome }}{\begin{array}{c}\text { Dominant } \\
\text { Party } \\
\text { Wins }\end{array}}$} & \multirow[b]{2}{*}{$\begin{array}{l}\text { No. of } \\
\text { Cases }\end{array}$} \\
\hline $\begin{array}{l}\text { Plaintiff's } \\
\text { Purpose Is } \\
\text { Restrictive }\end{array}$ & $\begin{array}{l}\text { Defendant's } \\
\text { Purpose Is } \\
\text { Restrictive }\end{array}$ & $\begin{array}{l}\text { Winner Is } \\
\text { Defendant }\end{array}$ & $\begin{array}{c}\text { No } \\
\text { Discretion }\end{array}$ & $\begin{array}{c}\text { Defendant } \\
\text { Has Stigma } \\
\text { Advantage }\end{array}$ & & \\
\hline 1 & 0 & 0 & 1 & 0 & 1 & 4 \\
\hline 0 & 1 & 1 & - & - & 1 & 3 \\
\hline 1 & 0 & 0 & 0 & 0 & $i$ & 4 \\
\hline 0 & 1 & 1 & 1 & - & 1 & 2 \\
\hline 0 & $i$ & 1 & 0 & - & 1 & 1 \\
\hline 1 & 0 & 1 & - & - & 1 & 1 \\
\hline 0 & 1 & 1 & - & 0 & 1 & 1 \\
\hline 1 & 0 & 1 & 1 & - & 1 & 1 \\
\hline 0 & 1 & 1 & 1 & 1 & 1 & 6 \\
\hline 1 & 1 & $i$ & 1 & 1 & 1 & 1 \\
\hline 0 & 1 & 0 & 1 & - & 0 & 3 \\
\hline 0 & $i$ & 0 & 0 & 1 & 0 & 1 \\
\hline 1 & 0 & 1 & - & 0 & 0 & 1 \\
\hline 0 & 1 & 0 & 0 & - & 0 & 1 \\
\hline 1 & 0 & 1 & 0 & 0 & 0 & 5 \\
\hline 1 & 0 & 0 & 0 & - & 0 & 1 \\
\hline
\end{tabular}

losses (dominant party wins $=0$ ) for dominant parties (losses by dominant parties, of course, mean wins by subordinate parties). A dash indicates that a value for that variable was not available in some cases (these values are called "don't cares" in Boolean algebra and are treated as "either 0 or 1 " for purposes of simplification). As table 2 indicates, we find 10 different ways in which dominant parties win in our data (representing a total of 24 wins) and 8 ways in which subordinate parties win (representing a total of 12 wins).

\section{Dominant Party Wins}

Table 3 presents the simplified configurations obtained from a qualitative comparative analysis of dominane party wins; that is, truth table rows with an outcome value of 1 from table 2. Configurations in a Boolean solution are connected to one another by a logical "or." Thus each alone represents an alternative set of relational attributes that will be present in cases when a dominant party wins. Together, the configurations summarize all the distinctive ways in which relational attributes combine when dominant parties win in our data.

According to the first configuration in table 3, dominant parties win when they press restrictive (counter)claims as defendants against subor- 
TABLE 3

\section{Relational Configurations for Dominant Parties Winning}

\section{Configurations}

1. Defendant wins and is making a restrictive case against the plaintiff's expansive claim

2. Defendant wins, has a restrictive purpose, has a stigma advantage, and both parties have no discretion but to remain in the relationship

3. Plaintiff wins, has a restrictive purpose, and has a stigma advantage

4. Defendant wins, has an expansive purpose

dinate plaintiffs making expansionary claims. For example, in Coffee $v$. Cutter Biological, ${ }^{88}$ the plaintiff asserts a product liability claim based on him acquiring AIDs against a commercial manufacturer of blood components who both denied liability and subsequently won.

The second configuration repeats the same claim relationships combined with the defendant/winner having a stigma advantage over the loser/plaintiff and both parties being wedded to the relationship. Fixed relationships are typically evident when claims emerge from the criminal justice sphere and other spheres involving state exercise of coercive powers (e.g., public education). The courts are most reluctant to interfere with the routines of state authorities exercising their coercive powers, particularly prison officials exercising their powers over inmates living with HIV/ AIDs. For example, in Doe v. Coughlin, ${ }^{89}$ a prisoner with AIDs sued and lost against the New York state corrections department in an effort to gain conjugal visits with his wife. Here, the anticipated effect of stigma seems to be operative, and the coerced relationship between the parties produces losses for subordinate parties.

We can combine the first two configurations from table $3^{90}$ into the following logical statement about dominant party wins:

Dominant parties win when: the dominant party is the defendant AND the dominant party makes a restrictive claim AND EITHER (the subordinate plaintiff makes an expansive claim) OR (the dominant party has a stigma advantage AND both parties have no discretion but to remain in the relationship).

Combining terms in this fashion reinforces our general argument that the nature of the claim brought by a party is important and also emphasizes

88. 809 F.2d 191 (2d Cir. 1987).

89. 509 N.Y.S.2d 209 (1986).

90. This procedure, called "hand factoring," takes advantage of the distributive property of Boolean algebra to gather together variables that are common to two or more configurations. It helps to focus attention on more abstract themes found in the configurations. 
how the relationship between parties and claims is associated with case outcomes. These two configurations combined account for over half (14 of 24) of the court cases in which dominant parties win.

Configuration 3 carries through the theme that prevailing restrictive claims, combined with the legal status of plaintiff, stigma advantage, and the lack of discretion to change relationships, produces wins for dominant parties. New St. Mark's Baths ${ }^{91}$ exemplifies this configuration, as it pits as defendants a gay bathhouse and individual gay intervenors against a regulatory authority seeking to close the bathhouse as a nuisance to public health.

The final configuration represents atypical cases in which a dominant party wins as a defendant pressing an expansive claim. These two cases represent both state and corporate interests acting so as to advance strategic goals of PWAs and their allies. In American Council of Life Insurance v. District of Columbia, ${ }^{92}$ life insurance companies failed in their attempt to negate a Washington, D.C., statute that forbade insurers from discriminating against individuals on the basis of test screening for AIDs. The statute was strongly supported by gay and civil rights organizations. In Rasmussen v. South Florida Blood Service, ${ }^{93}$ the court denied the claim made by a deceased's estate for a list of all blood donors from the defendant. In relegitimating the blood bank's authority to shield its clients, the court claimed that it acted to prevent discrimination due to disclosure. These cases reflect the court's showing a strong tendency to back claims where corporate and state interests converge with the interests of PWAs and their allies. Discrimination rationales and rights concerns are put forward by the courts under these conditions.

\section{Subordinate Party Wins}

Table 4 presents the combinations of relational attributes associated with wins for subordinate parties. ${ }^{94}$ The first two configurations reflect potentially extreme cases in which a stigmatized plaintiff or defendant wins while pressing an expansive claim. ${ }^{95}$ The first configuration shows defend-

91. 497 N.Y.S.2d 979 (1986).

92. 645 F. Supp. 84 (D.D.C. 1986).

93. 500 So.2d 533 (Fla. 1987).

94. See table 2 , rows with a value of " 0. "

95. Cases in which plaintiffs were pressing what we conceptualized initially as "expansionary" claims were actually of two types. Often, claims pressed by litigious individuals, particularly inmates, are more precisely reflective of people's use of law to engage in resistance politics. That is, people lacking an effective voice in society have turned to the appellate courts to resist unfair and arbitrary treatment by legislatures and state bureaucracies. See, e.g., Stuart Scheingold, The Politics of Rights: Lawyers, Public Policy and Political Change (New Haven, Conn.: Yale University Press, 1974); Bordt \& Musheno, 25 J. Res. Crime $\mathcal{E}^{2}$ Delinq. (cited in note 43). These claims are different from what Lynn Mather \& Barbara Yngvesson, 15 Law $\mathcal{E}$ Soc'y Rev. at 778-79 (cited in note 43), describe as an "expansionary" 


\section{TABLE 4}

\section{Relational Configurations for Subordinate Parties Winning}

\section{Configurations}

1. Defendant wins with an expansive purpose while plaintiff has a stigma advantage and there is discretion to change the relationship between the parties

2. Plaintiff wins with an expansive purpose

3. Plaintiff wins with a restrictive purpose in the face of defendants' stigma advantage and there is discretion to change the relationship between the parties

ants doing this in the face of a stigma disadvantage and in a market setting where relationships are not fixed or coerced by state authority. For example, in Yorkshire Towers Co. ${ }^{96}$ a gay life partner of a man who dies of AIDS successfully invoked rent control provisions allowing him continued occupancy of an apartment as a family member. ${ }^{97}$ Similarly, a plaintiff with AIDs in Shuttleworth ข. Broward County ${ }^{98}$ successfully obtained application of the 1973 Rehabilitation Act to his claim of employment discrimination based on his status as a PWA. Thus, the courts seem willing to support the liberty claims of PWAs fighting discrimination in the marketplace but reluctant to act on such claims when PWAs are operating inside state spheres endowed with coercive authority.

However, configuration 2 indicates that PwAs can win against state authorities, particularly when the PWA is viewed as an "innocent victim." Parents of children with HIV/AIDS were able in Ray ${ }^{99}$ to obtain a court order barring the segregation of their children. We will look more closely at the schoolchildren with HIV/AIDS cases in the conclusions.

We can combine configurations 1 and 2 from table 4 and make the

claim. Such a claim "challenges established categories for classifying events and relationships by linking subjects or issues that are typically separated, thus 'stretching' or changing accepted frameworks for organizing reality." In this study, we use the phrase "extreme cases" to denote cases where the courts sustain a claim that stretches or changes accepted frameworks.

96. 510 N.Y.S.2d 976 (1986).

97. The most noted AIDS case to date in which the court has expanded the meaning of family to include gay life partners is Braschi v. Stahl Associates 543 N.E.2d 49 (N.Y. Ct. App. 1989). Miguel Braschi nursed his lover Leslie Blanchard through his death from AIDS. They shared a rent-controlled apartment in New York City. Mr. Blanchard was the tenant on the lease. On his death, the landlord moved to evict Mr. Braschi since he had no legal relationship to the tenant of record. Mr. Braschi sued asking the court to expand its view of family. The court found that the term "family" should not be restricted to those who had formal evidence of it, such as a marriage license or an adoption order. Rather, the court suggested that a more appropriate determination of familial status would be to evaluate factors such as financial commitment, the exclusivity of the couple's relationship, and the reliance they placed on each other.

98. 639 F. Supp. 654 (S.D. Fla. 1986).

99. 666 F. Supp. 1524 (M.D. Fla. 1987). 
following logical statement about relational attributes associated with subordinate party wins.

Subordinate parties win when: the subordinate party makes an expansive claim AND EITHER (the subordinate party is a defendant AND the dominant party has a stigma advantage AND there is discretion to change the relationship between the parties) $O R$ (the subordinate party is a plaintiff).

Once again we see evidence of the link between party and claim. These two configurations together explain almost all (11 of 12) of the court cases in which subordinate parties win.

Configuration 3 represents unanticipated conditions in which a subordinate party wins by pressing restrictive claims to establish some degree of control over PWAs. The single case where this configuration is evident, Tarrant County Hospital District v. Hughes, ${ }^{100}$ was brought by the estate of a person who had contracted AIDs from a blood transfusion. The court allowed pretrial discovery of blood donor lists so that plaintiff might investigate those donors to establish negligence by the hospital which collected the blood. This configuration and the corresponding case are atypical of the way the courts have responded to disputes involving disclosure of blood donor identities.

\section{Interpretational Attributes and Case Outcomes}

Table 5 presents a truth table summarizing the different ways in which courts use interpretational factors to account for dominant party wins and losses. An interesting feature of this truth table is that two of the configurations have an outcome value of " 0 AND 1." This means that each of these configurations occurred in a court case in which the dominant party won and a case in which the subordinate party won. These configurations are noteworthy because they indicate that the same rationales were used to justify wins for dominant and subordinate parties. However, these are unusual circumstances, accounting for only 4 of our 36 cases. For purposes of analysis, we treated these configurations quite literally; that is, we included them in both the simplification of dominant party wins and the simplification of subordinate party wins. We believe that this approach is most consistent with our goal of trying to understand the variety of ways in which courts account for decisions in AIDS cases.

100. 734 S.W.2d 675 (Tex. App. 1987). 
TABLE 5

Truth Table Showing Configurations of Interpretational Attributes Associated with Dominant Party Wins and Losses

\begin{tabular}{|c|c|c|c|c|c|c|}
\hline \multicolumn{5}{|c|}{ Explanatory Variables $(0=$ No; $1=$ Yes $)$} & \multirow{2}{*}{$\begin{array}{c}\text { Outcome } \\
\text { Dominant } \\
\text { Party } \\
\text { Wins }\end{array}$} & \multirow[b]{2}{*}{$\begin{array}{l}\text { No. of } \\
\text { Cases }\end{array}$} \\
\hline $\begin{array}{l}\text { Trad. } \\
\text { Legal } \\
\text { Presups. } \\
\text { Used }\end{array}$ & $\begin{array}{l}\text { Nontrad. } \\
\text { Legal } \\
\text { Presups. } \\
\text { Used }\end{array}$ & $\begin{array}{c}\text { Court } \\
\text { Grants } \\
\text { Demand on } \\
\text { Rights }\end{array}$ & $\begin{array}{c}\text { Court } \\
\text { Defers to } \\
\text { Medical } \\
\text { Expertise }\end{array}$ & $\begin{array}{l}\text { Presence } \\
\text { of AIDS } \\
\text { Metaphors }\end{array}$ & & \\
\hline 1 & 0 & 0 & 1 & 1 & 1 & 6 \\
\hline 1 & 1 & 1 & 1 & 1 & 1 & 2 \\
\hline 1 & 0 & 0 & 0 & 1 & 1 & 3 \\
\hline 1 & 0 & 0 & 0 & 0 & 1 & 2 \\
\hline 1 & 0 & - & 0 & 0 & 1 & 2 \\
\hline 1 & 0 & - & 1 & 0 & 1 & 1 \\
\hline 0 & 0 & $\ldots$ & 0 & 1 & 1 & 1 \\
\hline 1 & 0 & - & 0 & 1 & 1 & 2 \\
\hline 0 & 0 & - & 1 & 1 & 1 & 1 \\
\hline 0 & 0 & 0 & 0 & 0 & 1 & 2 \\
\hline 1 & 0 & 1 & 1 & 1 & 0 & 1 \\
\hline 0 & 0 & 1 & 0 & 0 & 0 & 4 \\
\hline 0 & 0 & 0 & 1 & 0 & 0 & 1 \\
\hline 0 & 1 & - & 0 & 0 & 0 & 1 \\
\hline 1 & 1 & 1 & 1 & 0 & 0 & 1 \\
\hline 0 & 1 & - & 1 & 1 & 0 & 1 \\
\hline 0 & 1 & - & 0 & 1 & 0 & 1 \\
\hline 0 & 1 & 1 & 0 & 0 & 0 AND 1 & 2 \\
\hline 0 & 0 & - & 0 & 0 & 0 AND 1 & 2 \\
\hline
\end{tabular}

\section{Dominant Party Wins}

Table 6 lists the simplified interpretational configurations associated with wins for dominant parties. The first two configurations reveal that dominant parties win when judges utilize traditional legal presuppositions, avoid the use of nontraditional legal presuppositions, and either avoid the use of divisive AIDS metaphors or utilize notions of rights. This supports our expectation that the use of traditional legal presuppositions will support relative positions of power and the status quo. For example, in Kozup v. Georgetoun University, ${ }^{101}$ the court strikes down the request of a PWA for compensation for negligent blood transfusions, referring to "reason" and "reasonableness" seven separate times in the decision. ${ }^{102}$

101. 663 F. Supp. 1048 (D.D.C. 1987).

102. Deference to "reason" occurred in 14 of the 21 cases where one or more traditional legal presuppositions were present. To avoid overidentifying references to "reason" as a traditional presupposition in the text, we excluded from consideration references to a legal "reasonableness" test and checked its contextualization in every case where it was recorded as present. 
Court Interpretational Configurations for Dominant Parties Winning

\section{Configurations}

1. Traditional legal presuppositions are used by the court, nontraditional legal presuppositions are not used, and AIDS metaphors are not used

2. Traditional legal presuppositions are used by the court, nontraditional legal presuppositions are not used, and legal or statutory rights, while cited, are not the basis for the court's decision

3. AIDS metaphors are present and there is no nontraditional legal presuppositions or deference to medical authority

4. AIDS metaphors are present and there are no traditional or nontraditional legal presuppositions utilized

5. Rights, while cited, are not utilized, and there is an absence of any deference to medical authority, and nontraditional legal presuppositions

6. AIDS metaphors are present, as are traditional and nontraditional legal presuppositions; medical authority is deferred to, and the court uses constitutional or statutory rights as the basis for its decision

As revealed in configurations 3 and 4, divisive AIDS metaphors do show up in other contexts where the courts back the claims of dominant parties. For example, in Cheney v. Bell National Life Insurance, ${ }^{103}$ the panel of judges saw AIDs as "uniformly lethal" and "dreaded" in a decision which ruled that acquiring HIV/AIDs through a transfusion was not an accident for purposes of life insurance. Cultural bias, reflected in judicial use of emotionally laden metaphors, undergirds a number of configurations in which dominant parties secured wins in the early years of AIDS-related litigation. In such cases, it fills the text when other, potential interpretational options are neglected or absent. These configurations may reflect the fear of AIDS and contagion felt by judges operating with limited knowledge.

The solution for interpretational attributes reported in table 6 is more complex than the one for relational attributes (table 3). However, by combining the attributes that are common to the configurations, we can make an important generalization about how courts justify wins for dominant parties. Note that the absence of nontraditional legal presuppositions is a variable common to five of the six simplified configurations in table 6 . These five configurations together account for almost all (22 of 24) of the actual court cases in which dominant parties win. This means that a crucial feature for distinguishing accounts of dominant party wins from accounts of subordinate party wins is the unwillingness of courts to contradict core liberal values or to act on the basis of dissident rationales.

In Two Associates v. Brown, ${ }^{104}$ the court referred to both constitutional

103. 520 A.2d 402 (Md. App. 1987).

104. 513 N.Y.S.2d 966 (1987). 
and statutory rights as being potentially applicable but failed to apply these rights in denying access by a surviving gay life partner to rent controlled housing. The number of cases with dominant parties winning with the unique configuration of courts acknowledging rights but not using them reinforces the CLS perspective that there are rationales or idea structures at work other than those derived from rights and doctrine.

Configuration 6 is further revealing of unanticipated cases in which dominant parties win while pressing expansionary claims. The two cases containing this configuration involve state or city boards of education contesting the actions of local education boards which had excluded children with HIV/AIDs from regular school programs. We discuss the implications of these cases in the conclusions below.

\section{Subordinate Party Wins}

Table 7 lists the simplified configurations of interpretational attributes associated with subordinate party wins (rows with an outcome value of 0 from the truth table in table 5). While some overlap can be found across those terms, they are generally more distinctive (and thus less amenable to further simplification) than those in the previously reported solutions. This, in itself, is an interesting finding. It suggests, as we might expect, that courts which go against dominant parties in the AIDs sociolegal network and side with subordinate parties do not always have recourse to a well-defined set of rationales.

However, the courts do show a tendency to draw on nontraditional legal presuppositions as revealed in the first two configurations. For example, the judge in People v. Camargo" 105 followed the principle of "compassion" in dismissing a criminal indictment against a person who was dying of AIDS, and in Yorkshire Towers Co. ${ }^{106}$ the judge gave "weight to the emotional bond" between gay life partners in establishing a quasi-marital relationship for purposes of rent control.

In configurations 3,4 , and 5 , medical authority was deferred to in cases involving insurability and the education of children with AIDs. It seems to have been used by plaintiffs and accepted by the court as authority for plaintiff's claims, suggesting that the courts are swayed to support subordinate parties when their claims are backed by the utility claims of public health/medical authorities about how to best manage the disease. Subordinate parties can use the superior standing of public health/medical authorities to bolster their (counter)claims, and such use may provide a potential route for winning in the courts.

Rights were also used for decisional authority in configurations 3,4 ,

105. 516 N.Y.S.2d 1004 (1986).

106. 510 N.Y.S.2d 976 (1986). 
TABLE 7

Court Interpretational Configurations for Subordinate Parties Winning

\section{Configurations}

1. Nontraditional legal presuppositions are used by the court, traditional legal presuppositions are not used, and AIDS metaphors are present

2. Nontraditional legal presuppositions are used by the court, traditional legal presuppositions are not used, and medical authority is not deferred to

3. AIDS metaphors are not present, both traditional and nontraditional legal presuppositions are present, medical authority is deferred to and rights are used by the court as a basis for its decision

4. AIDS metaphors are present, as are traditional, but not nontraditional legal presuppositions, medical authority is deferred to and rights serve as a basis for the court's decision

5. Constitutional or statutory rights serve as a basis for the court's decision, and there is an absence of legal presuppositions, AIDS metaphors, and deference to medical authority

6. Medical authority is deferred to, and there is an absence of AIDS metaphors and legal presuppositions

and 5. But in nearly half the cases, the subordinate party was seeking to limit the privacy rights of those with AIDS or the court decision failed to advance an expansionary claim. For example, in Shelvin थ. Lykos, ${ }^{107}$ an appeals court said that the trial court had no authority at the time to order an AIDS test for a defendant, sending the case back to the trial court while noting a legislative change which now allowed it. Similarly, in People v. McGreevy, ${ }^{108}$ an appeals court ruled that the trial court had no authority to impose an AIDS test as a condition of bail but increased the defendant's bail from $\$ 2,500$ to $\$ 10,000$. Thus, rights seem indeterminate of wins for subordinate parties where expansionary claims are backed by courts. When dominant parties win, rights generally are cited but not used, while their more active use with subordinate party wins is often not reflective of an expansionary claim being legitimated by the courts. ${ }^{109}$

\section{DISCUSSION AND CONCLUSIONS}

Our findings establish that the courts show a strong tendency to legit-

107. 741 S.W.2d 178 (Tex. App. 1987).

108. 514 N.Y.S.2d 622 (Sup. 1987).

109. Like Kelman, Guide 258 (cited in note 18), Unger, Critical Legal Studies Movement (cited in note 22), argues that the indererminism of rights derives from the fact that legal rules derive from structures of thought that are fundamentally contradictory. Taking a somewhat different position, Elizabeth Mensch, "The History of Mainstream Thought," in Kairys, Politics 31 (cited in note 12), argues that the rights claim that will be utilized by the court fluctuates relative to context and will be status or relationship dependent. 
imate the standing of dominant parties in the emergent AIDS sociolegal network. In so doing, the courts lent support to restrictive claims, showed a great reluctance to give equal standing to stigmatized parties, employed divisive AIDS metaphors to rationalize their decisions, relied on traditional legal presuppositions to justify rulings, and used the language of rights while selectively applying rights to manage AIDS contestations.

At the same time, we establish that the courts were occasionally supportive of PWAs in the early years of the epidemic. What organizational routes and sociolegal formats do we find evident when the courts blocked repression measures or, in rare cases, upheld claims seeking to redefine social and cultural boundaries?

Dominant parties sometimes work in consort with PWAs to block restrictive, even repressive, claims advanced by less dominant parties. State parties are especially active in this regard, and the courts often support the efforts of these parties, particularly when "innocent victims" are the targets of repression. The phenomenon of state-AIDS parties alliances is most evident with regard to how children with HIV/AIDS were handled in the public schools during the early years of the epidemic. In that situation community-based parties, in the form of local school boards, initiated legal action to restrict severely the children's access to public schools. State parties, mostly centralized education and public health authorities, countered these efforts and usually received the full backing of the courts (see Board of Education v. Cooperman, ${ }^{10}$ District 27 Community School Board v. Board of Education of the City of New York). ${ }^{111}$

These findings are consistent with the politics of resistance literature which argues that the "densely interdependent relations" of social life serve as a source of power for marginalized parties ${ }^{112}$ and studies which suggest that progressive forces operate within, as well as outside, the bowels of the bureaucratic order in resistance to repression. ${ }^{113}$ Also, these findings are supported by the emerging literature on the social ecology of AIDS which indicates that public health agencies and other state parties, like human rights' commissions, are forming effective alliances with AIDS parties, including gay rights organizations. ${ }^{114}$ Overall, state bureaucracies, much like the courts, operate as double-edged institutions that sometimes

110. 507 A.2d 253 (N.J. Super. 1986).

111. 502 N.Y.S.2d 325 (1986).

112. For example, see Piven, 28 Soc. Probs. 489 (cited in note 42); Handler, Conditions of Discretion (cited in note 41).

113. Henry, 19 Law 8 Soc'y Rev. 303 (cited in note 40); Michael Musheno, "Justice Motive in Social Policy Implementation," 5 Policy Stud. Rev. 697 (1986); B. Dan Wood, "Principals, Bureaucrats, and Responsiveness in Clean Air Enforcements," $82 \mathrm{Am}$. Pol. Sci. Rev. 213 (1988).

114. See, e.g., Jane Aiken, "Education as Prevention," in Dalton et al., AIDS 90 (cited in note 3 ). 
work in alliance with marginalized parties, at least during the onslaught of modern disease scares.

In addition to showing that state-AIDs party alliances provide one route for advancing the claims of persons with AIDS, we look to freestanding wins of subordinate parties to uncover sociolegal formats that may be replicated to resist repression and advance expansionary claims in the courts. Plaintiffs and defendants with status disadvantages are more likely to be successful in pressing expansionary claims in situations in which one or more of the contesting parties have discretion to terminate their relationship. For example, in Yorkshire Towers Co. ${ }^{115}$ the gay life partner of a man who died of AIDs successfully invoked rent control provisions allowing him continued occupancy of an apartment as a family member. And our interpretational configurations indicate that judges may be open to arguments which advance nontraditional legal presuppositions amid the tragedies of a lethal epidemic (see Yorkshire Towers Co.). ${ }^{116}$ Finally, a number of interpretational configurations indicate that the courts are swayed to support PWAs when their claims are backed by the utility claims of public health authorities about how to best manage the disease.

We must conclude with a cautionary note about the current application of the organizational arrangements and sociolegal formats that served the interests of persons with AIDS and their allies in the early years of the epidemic. The most expansionary claims advanced by subordinate parties in the early years addressed issues of discrimination and the redistribution of status relative to the disease first striking the gay white male communities of large urban cities. Courts have historically showed a sensitivity to issues of discrimination, particularly in housing and the workplace, and these affected populations have a community identity, substantial resources at their disposal, and are represented in state agencies with responsibility for managing epidemics.

As AIDS is now a growing problem for people of color residing in the inner cities, both the potential disputants and the nature of claims making are likely to change. In that the most pressing needs of this population revolve around calls for a redistribution of tangible resources, particularly health-related goods and services and drug treatment, we have doubts that the courts have either the will or capacity to play a meaningful role in the evolving social ecology of AIDs. Moreover, these affected communities have fewer resources, and because of the connection between AIDs and the inner-city IV-drug subculture, the leadership of these communities (e.g., church leadership) has yet to lend its full support to the social struggles against AIDS.

115. 510 N.Y.S.2d 976 (1986).

116. Id. 


\section{APPENDIX A}

\section{PUBLISHED AIDS CASES 1983-1987}

Cases Analyzed in This Study Signified by "+"

+ American Council of Life Ins. v. District of Columbia, 645 F. Supp. 84 (D.D.C. 1986).

Baker v. Wade, 106 F.R.D. 526 (1985).

+ Barlow v. Superior Court (People), 236 Cal. Rptr. 134 (Cal. App. 1987).

+ Berg v. Health \& Hosp. Corp. of Marion County, 667 F. Supp. 639 (S.D. Ind. 1987).

+ Blair v. United States, 525 A.2d 170 (D.C. App. 1987).

+ Board of Educ., Plainfield v. Cooperman, 523 A.2d 655 (N.J. 1987).

+ Board of Educ. v. Cooperman, 507 A.2d 253 (N.J. Super. Ct. 1986).

+ Broadway Books v. Roberts, 642 F. Supp. 486 (E.D. Tenn. 1986).

+ Cheney v. Bell Nat'l Life Ins., 520 A.2d 402 (Ct. App. Md. 1987).

+ City of New York v. New St. Mark's Baths, 497 N.Y.S.2d 979 (1986).

+ Coffee v. Cutter Biological, 809 F.2d 191 (2d Cir. 1987). Conkel v. Conkel, 509 N.E.2d 783 (Ct. App. Ohio 1987).

Cordero v. Coughlin, 607 F. Supp. 9 (Dist. Ct. N.Y. 1984).

Davis v. Tuscaloosa County Sheriff's Dep't, 1987 U.S. Dist. LEXIS 10246.

+ District 27 Comm. School v. Board of Educ., 502 N.Y.S.2d 325 (1986). Doe v. Coughlin, 505 N.Y.S.2d 534 (Sup. Ct. N.Y. 1986).

+ Doe v. Coughlin, 509 N.Y.S.2d 209 (1986).

Doe v. Coughlin, 518 N.E.2d 536 (N.Y. 1987).

Doe v. Doe, 519 N.Y.S.2d 595 (Sup. Ct. 1987).

Doe v. Belleville Pub. School Dist. No. 118, 672 F. Supp. 342 (S.D. Ill. 1987).

Doe v. Miles Laboratories, Cutter Laboratories Div., 675 F. Supp. 1466 (Dist. Ct. Md. 1987).

Doe v. New Haven Independent, Inc., 549 A.2d 683 (Conn. 1987).

Randall v. Alcohol Mental Health Ass'n, 1986 WL 157 (E.D. Pa. 1986).

+ Feigley v. Jeffes, 510 A.2d 385 (Commw. Ct. Pa. 1986).

Feigley v. Jeffes, 522 A.2d 179 (Cmmwlth. Ct. Pa. 1987).

Fenton v. City of Philadelphia, 1986 WL 10560 (E.D. Pa. 1986).

Foy v. Owens, 1986 WL 5564 (E.D. Pa. 1986).

Gregory E. Thagard v. County of Cook, 1985 WL 1495 (N.D. Ill. 1985).

+ Haywood County v. Hudson, 740 S.W.2d 718 (Tenn. 1987).

In re Peacock, 59 B.R. 568 (Bankr. S.D. Fla. 1986).

Jane W. v. John W., 519 N.Y.S.2d 603 (1987). 
Jarrett v. Faulkner, 662 F. Supp. 928 (S.D. Ind. 1987).

Jones v. Miles Laboratories, 705 F. Supp. 561 (N.D. Ga. 1987).

+ Judd v. Packard, 669 F. Supp. 741 (Dist. Ct. Md. 1987).

+ Kentucky Cent. Life Ins. Co. v. Webster, 651 F. Supp. 935 (N.D. Ala. 1986).

Klein v. Panic, 1986 WL 438 (Del. Ch. 1986).

+ Kozup v. Georgetown Univ., 663 F. Supp. 1048 (D.D.C. 1987).

Krygier v. Airweld, Inc., 520 N.Y.S.2d 475 (N.Y. Sup. Ct. 1987).

LaRocca v. Dalsheim, 467 N.Y.S.2d 302 (N.Y. Sup. Ct. 1983).

+ Local 1812 Am. Fed'n of Gov't Employees v. Dep't of State, 662 F. Supp. 50 (D.D.C. 1987).

M., on Behalf of S. v. R., 487 N.Y.S.2d 685 (Fam. Ct. N.Y. 1985).

Martinez v. School Bd. of Hillsborough County, 675 F. Supp. 1574 (M.D. Fla. 1987).

Matter of Commitment of B.S., 517 A.2d 146 (N.J. Super. Ct. A.D. 1986).

McKee v. Miles Laboratories, 675 F. Supp. 1060 (E.D. Ky. 1987).

+ McDuffie v. Rikers Island Medical Dep't, 668 F. Supp. 328 (S.D.N.Y. 1987).

+ Miles Lab. v. Superior Court, 220 Cal. Rptr. 590 (Cal. App. 1986).

Muhammad v. Frame, 1987 WL 16889 (E.D. Pa. 1987).

Parents of Child, Code No. 870901W v. Coker, 676 F. Supp. 1072 (E.D. Okla. 1987).

Pawlisch v. Barry, 376 N.W.2d 368 (Wis. App. 1985).

+ People ex rel. Glass on Behalf of Ryan v. McGreevy, 514 N.Y.S.2d 622 (Sup. Ct. 1987).

+ People v. Camargo, 516 N.Y.S.2d 1004 (1986).

+ People v. Parker, 517 N.Y.S.2d 783 (1987).

Poff v. Caro, 549 S.2d 900 (N.J. 1987).

Powell v. Department of Corrections, 647 F. Supp. 968 (N.D. Okla. 1986).

+ Rasmussen v. South Fla. Blood Serv., 500 So. 2d 533 (Fla. 1987).

+ Ray v. School Dist. of Desoto County, 666 F. Supp. 1524 (M.D. Fla. 1987).

Roberts v. Suburban Hosp. Ass'n, 531 A.2d 1081 (Md. 1987).

Savino v. Nassau Hosp., 511 N.Y.S.2d 379 (A.D. 2 Dept. 1987).

Schneider v. Flowers, 521 N.Y.S.2d 647 (1987).

+ Seitzman v. Hudson River Assocs., 513 N.Y.S.2d 148 (1987).

+ Shelvin v. Lykos, 741 S.W.2d 178 (Tex. App. 1987).

+ Shutrleworth v. Broward County, 639 F. Supp. 654 (S.D. Fla. 1986). South Fla. Blood Service Inc. v. Rasmussen, 467 So.2d 798 (Fla. App.

3 Dist. 1985).

Sparks v. Metalcraft, Inc., 408 N.W.2d 347 (Iowa 1987). 
State v. Van Straten, 409 N.W.2d 448 (Wis. App. 1987).

+ State v. Waymire, 504 S.2d 953 (La. App. 1987).

State v. Wright, 534 A.2d 31 (N.J. 1987).

State Dep't of Correction v. Delaware Pub. Employees Council 82, 1987 WL 5979 (Del. Ch. 1987).

State of Ga. v. Fleck, 622 F. Supp. 256 (D.C. Ga. 1985).

Storms v. Dep't of Correctional Servs., 1986 WL 4704 (S.D.N.Y. 1986).

+ Tarrant County Hosp. Dist. v. Hughes, 734 S.W.2d 675 (Tex. App. 1987).

+ Thomas v. Atascadero Unified School Dist., 662 F. Supp. 376 (C.D. Cal. 1987).

Torres v. City of Philadelphia Police Dept. Sex Crime Unit, 1986 WL 10553 (E.D. Pa. 1986).

Traufler v. Thompson, 662 F. Supp. 945 (N.D. Ill. 1987).

+ Two Associates v. Brown, 513 N.Y.S.2d 966 (1987).

+ United States v. Kazanback, 824 F.2d 649 (8th Cir. 1987).

+ United States v. Moore, 669 F. Supp. 289 (D. Minn. 1987).

+- Williams v. Sumner, 648 F. Supp. 510 (D. Nev. 1986).

+ Yorkshire Towers Co. v. Harpster, 510 N.Y.S.2d 976 (1986).

Zachery Trading v. Northwestern Mut. Life Ins. Co., 668 F. Supp. 343 (D.C.N.Y. 1987). 


\section{Review Section}

\section{Edited by Howard S. Erlanger}

\section{REVIEW ESSAYS}

Why American Lawyers Should Go to India: Retracing Galanter's Intellectual Odyssey

Clark D. Cunningham

Loyalty and Betrayal: Cotterrell's Discovery and Reproduction of Legal Ideology

Susan S. Silbey

Justice at Home: Okin's Justice, Gender, and the Family

Sara Rapport

Howard S. Erlanger is professor of law and sociology at the University of Wisconsin, Madison. 
HeinOnline -- 16 Law \& Soc. Inquiry 7761991 